\title{
Pengembangan Modul Elektronik Dengan Feedback Berbasis Android Materi Suhu Dan Kalor Untuk Siswa SMA/MA
}

\author{
Amaliyah Tazkiyah, Sulur*, Sahal Fawaiz \\ Pendidikan Fisika, Universitas Negeri Malang \\ *Email: sulur.fmipa@um.ac.id
}

Received: 29 Februari 2020;

Accepted: 17 Maret 2020;

Published: 19 Maret 2020

DOI: http://dx.doi.org/10.29303/jpft.v6i1.1731

\begin{abstract}
The integration of ICT in the learning process has a positive effect on students' concepts understanding and learning interests. Android is a learning media tool that can store lots of interesting learning materials, such as electronic modules. This study was conducted to determine the feasibility of an Android-based electronic module with temperature and heat material feedback for high school / MA students. This research method is used in the ADDIE model (analysis, design, development, implementation, and evaluation). The electronic module was tested for validation by the validator with an average value of 3.49 and the module readability test with respondents of 85 students who obtained an average value of $79.3 \%$. Based on the data obtained, it can be conclude that the electronic module has decent criteria.
\end{abstract}

Keywords: electronic module; android; feedback

\section{PENDAHULUAN}

Teknologi informasi dan komunikasi (TIK) berkembang sangat pesat menyebabkan terjadinya perubahan pada segala bentuk aktivitas salah satunya pada sektor Pendidikan. Siswa lebih mudah mengakses materi dengan sangat efektif dan efisien (Conde and Fonseca 2018).

Hal ini mendukung perubahan dari pembelajaran berpusat pada guru menjadi berpusat pada siswa (Mihaela and Magdalena 2017) dan juga meningkatkan regulasi diri siswa (Herawati, 2017); (YotDomínguez \& Marcelo, 2017). Pengaruh teknologi pada pendidikan telah menumbuhkan pembelajaran berbasis jaringan sehingga memudahkan kolaborasi tanpa memperdulikan jarak (Mariki, 2013); (Rahman, 2014).

Integrasi TIK dalam pembelajaran memiliki banyak bentuk bergantung dengan spesifikasi dan tujuan masing-masing. Seperti simulasi virtual (Arianti et al. 2017), multimedia interaktif (Yulianci, Gunawan, and Doyan 2017), dan laboratorium virtual
(Sugiana et al. 2017) yang dapat membantu siswa meningkatkan penguasaan konsep. Media pembelajaran berbasis Moodle juga berperan dalam membantu siswa memahami konsep fisika yang abstrak (Herayanti et al. 2018). Di sisi lain, penilaian juga dipermudah dengan penggunaan $e$ assessment, selain mengurangi penggunaan kertas dan umpan balik diberikan secara langsung, tingkat obyektivitas penilaian menggunakan e-assessment cukup tinggi (Sahidu et al. 2017).

Salah satu integrasi TIK yang mudah digunakan adalah android, karena android merupakan salah satu sistem yang banyak digunakan dan open source (Yoon 2012). Seiring dengan meluasnya kemajuan bidang teknologi informasi dan komunikasi, serta ditemukannya dinamika proses belajar, pelaksanaan kegiatan belajar mengajar semakin menuntut adanya variasi media pembelajaran pada pendidikan (Fathoni and Marpanaji 2018).

Media pembelajaran android memiliki dampak positif terhadap performa belajar 
siswa. Penggunaan android sebagai laboratorium virtual dapat meningkatkan kemandirian belajar dan pemahaman konsep (Arista and Kuswanto 2018) literasi sains (Arifah \& Rosdiana, 2018), berpikir divergen, kemampuan berpikir tingkat tinggi (Mardiana and Kuswanto 2017) motivasi, minat, dan hasil belajar siswa (Widyawati and Prodjosantoso 2015). Fungsi media dalam proses pembelajaran untuk meningkatkan aktivitas siswa dalam belajar (Ali 2009).

Suhu dan kalor ialah salah satu konsep fisika yang penting karena sering dijumpai dalam kehidupan (Rahayu, Prastowo, and Harijanto 2019) Konsep suhu dan kalor sering dijumpai pada kehidupan sehari-hari. Namun masih terdapat siswa yang kesulitan dalam memahami konsepnya. Hal ini menyebabkan siswa tidak memenuhi standar minimal ketuntasan.

Penelitian yang dilakukan Agustin, Wahyuni, \& Bachtiar, (2018) dan Widyawati $\&$ Prodjosantoso, (2015), menyatakan bahwa rendahnya nilai Fisika yang diperoleh siswa disebabkan karena bahan ajar yang diberikan mempunyai tampilan yang kurang menarik. Ghaliyah, Bakri, \& Siswoyo (2015) menjelaskan bahwa persentase indikator kesulitan memahami kebahasaan pada buku cetak sebesar $66,67 \%$, dan ilutrasi pada buku cetak tersebut belum tepat mencerminkan konsep sama sekali (100\%.) Hal tersebut menyebabkan kurang maksimalnya peningkatan kompetensi dan hasil belajar pada peserta didik.

Berdasarkan hasil analisis peneliti, telah banyak pendidik yang kesulitan dalam memberikan evaluasi saat siswa mengerjakan soal. Pada hasil pekerjaan siswa hanya tertera nilai saja tanpa tahu benar atau salah. Hal tersebut menyebabkan kurang optimalnya pemahaman siswa terhadap materi yang dipelajari. Penyediaan correcctive feedback akan berhasil membantu kesulitan belajar siswa, karena siswa akan mengetahui alasan jawaban yang salah secara lengkap (Hörisch, Wulfsberg, and Schaltegger 2019). Dengan demikian, dibutuhkan fitur feedback atau umpan balik pada sebuah bahan ajar.

Berdasarkan latar belakang di atas peneliti akan melakukan penelitian dengan judul "Pengembangan Modul Elektronik dengan Feedback Berbasis Android Pada Materi Suhu dan Kalor untuk Siswa SMA/MA". Tujuan dari penelitian ini adalah mengembangkan modul elektronik materi Suhu dan Kalor serta mengetahui respon tim ahli serta pengguna terhadap kelayakan media pembelajaran tersebut. Harapannya, jika informasi atau pengetahuan dengan bantuan media yang akan dikembangkan dapat tersampaikan dengan baik pada siswa, maka keberhasilan pembelajaran bisa dicapai sehingga angka pada standar minimal kentuntasan dapat diatasi

\section{METODE PENELITIAN}

Desain penelitian dan pengembangan ini menggunakan model ADDIE (Analysis, Design, Development, Implementation, Evaluation). Tujuan dari penelitian ini yaitu untuk menghasilkan produk dan menguji kelayakan produk serta mengevaluasi produk. Terdapat 5 langkah yang diterapkan dalam model pengembangan ADDIE ini, yaitu analisis, desain, pengembangan implementasi dan evaluasi.

Metode pengumpulan data yang digunakan adalah dari hasil observasi dan wawancara untuk memperoleh data penelitian awal. Selain itu, pengumpulan data hasil pengembangan akhir, dilihat melalui angket oleh tim ahli media, tim ahli materi dan pengguna tentang kualitas dan kelayakan modul elektronik ini. Hasil yang diperoleh digunakan sebagai bahan pertimbangan dalam memperbaiki media pembelajaran. 
Dalam penelitian ini, analisis kepada validator menggunakan skala likert 1 sampai dengan skala 4 yang diadaptasi oleh Sugiono (2015)

Skor rata-rata total dari setiap komponen dengan teknik analisis sebagai berikut.

Keterangan

$$
\bar{x}=\frac{\sum f_{x}}{n}
$$

$$
\begin{array}{ll}
\overline{\mathrm{x}} & =\text { rata-rata kelayakan } \\
\Sigma \mathrm{x} & =\text { jumlah data.skor dari masing-masing item } \\
\mathrm{n} & =\text { banyak responden }
\end{array}
$$

Berdasarkan jawaban rata-rata yang diperoleh, kemudian ditentukan kelayakan dari produk modul elektronik dengan feedback berbasis android materi suhu dan kalor yang dikembangkan berdasarkan Tabel 1 .

Tabel 1. Kriteria Validasi Tiap Item

\begin{tabular}{cl}
\hline $\begin{array}{c}\text { Nilai } \\
\text { rata-rata }\end{array}$ & \multicolumn{1}{c}{ Kriteria Validitas } \\
\hline $3,2-4,0$ & Valid (tidak perlu revisi) \\
$2,2-3,1$ & Valid (perlu direvisi sebagian) \\
$1,2-2,1$ & Kurang valid (revisi sebagian dan \\
& pengkajuan ulang isi/materi) \\
$0,0-1,1$ & Tidak valid (revisi total/ diganti) \\
\hline
\end{tabular}

(Diadaptasi dari Arikunto, 2006)

Angket yang digunakan untuk uji keterbacaan menggunakan skala 1 sampai 5 yang ditunjukkan pada Tabel 2 .

Tabel 2. Kriteria Jawaban Uji Keterbacaan oleh Siswa dalam Skala Likert

\begin{tabular}{cc}
\hline Angka & Kriteria Validitas \\
\hline 5 & Sangat Setuju \\
4 & Setuju \\
3 & Netral \\
2 & Tidak Setuju \\
1 & Sangat Tidak Setuju \\
\hline & (Diadaptasi dari Sugiono, 2015)
\end{tabular}

Teknik analisis yang digunakan untuk menganalisis data hasil keterbacaan adalah teknik perhitungan presentase. Persamaan untuk menghitung nilai presentase sebagai berikut.

$$
x=\frac{\Sigma x}{\Sigma x_{i}} \times 100 \%
$$

Keterangan:

$\begin{array}{ll}\mathrm{X} & =\text { nilai persentase } \\ \Sigma \mathrm{x} & =\text { skor yang diperoleh } \\ \Sigma \mathrm{x}_{\mathrm{i}} & =\text { skor maksimal }\end{array}$

Tabel 3. Kriteria Hasil Uji Keterbacaan oleh

\begin{tabular}{cc}
\multicolumn{2}{c}{ Siswa } \\
\hline Rata-rata & Kriteria Validitas \\
\hline $76 \%-100 \%$ & Terbaca \\
$51 \%-75 \%$ & Cukup Terbaca \\
$26 \%-50 \%$ & Kurang Terbaca \\
$10 \%-25 \%$ & Tidak Terbaca \\
\hline
\end{tabular}

(Diadaptasi dari Arikunto, 2006)

\section{HASIL DAN PEMBAHASAN}

Pada tahap analyze dilakukan studi lapangan yaitu wawancara kepada salah satu guru fisika serta siswa kelas XI MIPA. Hasil wawancara tersebut diperoleh bahwa siswa sering mengeluh saat mempelajari fisika. Fisika menjadi salah satu pelajaran yang menakutkan bagi siswa karena banyak menggunakan rumus sehingga siswa menganggap fisika merupakan operasi matematis saja tanpa memahami proses fisisnya. Untuk mengerjakan soal pun, siswa harus dituntun untuk mengubah kalimat menjadi operasi matematika.

Saat ini sudah terdapat bahan ajar berbasis android untuk menunjang kegiatan pembelajaran. Beberapa modul elektronik tersebut diantaranya modul elektronik berbasis android materi suhu dan kalor untuk siswa SMA/MA dan buku siswa elektronik berbasis android pada materi suhu dan kalor untuk persiapan ujian nasional SMA/MA. Pada bahan ajar yang pertama, tidak adanya feedback dalam pengerjaan soal. Pada bahan ajar yang kedua berfokus pada ujian nasional.

Media pembelajaran berupa bahan ajar dapat berguna bagi guru dalam melaksanakan pembelajaran. Berdasarkan hasil wawancara yang telah dilakukan, diperoleh bahwa guru hanya mengikuti bahan ajar yang telah disediakan oleh sekolah yaitu berupa buku cetak, sebagai 
sumber belajar. Selain itu, proses pembelajaran yang dilakukan oleh guru masih menggunakan metode ceramah kemudian diberi kuis. Kurangnya media yang mendukung dapat memengaruhi minat serta hasil belajar siswa dalam mencapai ketuntasan. Pada saat pengoreksian jawaban ulangan siswa, diperoleh 2-5 siswa yang tuntas.

Setelah melakukan wawancara, diperoleh informasi bahwa beberapa materi fisika yang sulit dipahami bagi siswa, antara lain GLB, GLBB, Kesetimbangan Benda Tegar, Hukum Newton Gravitasi, Hukum Bernouli, Kapasitas Kapasitor, dan asas black pada materi Suhu. Dengan mempertimbangkan segala aspek, materi yang akan digunakan dalam penelitian ini adalah materi Suhu dan Kalor.

Modul elektronik ini, akan dibuat dengan bantuan Microsoft Office Power Point dengan bantuan software lain seperti Website 2 APK Builder, i-Spring, Photoshop, Corel Draw dan Paint. Berdasarkan hasil analisis di atas, diperoleh kesimpulan bahwa diperlukan modul elektronik berbasis android dengan feedback pada materi Suhu dan Kalor untuk siswa SMA/MA.

Pada tahap design ini didapatkan berupa kerangka modul elektronik yang akan dikembangkan, ditunjukkan pada Gambar 1. Modul elektronik ini berisi 11 fitur yaitu petunjuk penggunaan modul, peta konsep, ringkasan materi, contoh soal, latihan soal, penerapan dalam kehidupan sehari-hari, pratikum, kuis, daftar pustaka, buku digital dan author.

Dalam validasi konten, terdapat 8 aspek yang menjadi penialaian oleh validator meliputi aspek materi, contoh soal, latihan soal, penerapan, pratikum, buku digital, peta konsep dan kuis. Modul elektronik yang dikembangkan tetap melakukan revisi berdasarkan komentar dan juga saran yang diberikan oleh Validator. Rekapitulasi hasil validasi konten yang diberikan oleh validator ditunjukkan pada Tabel 4.

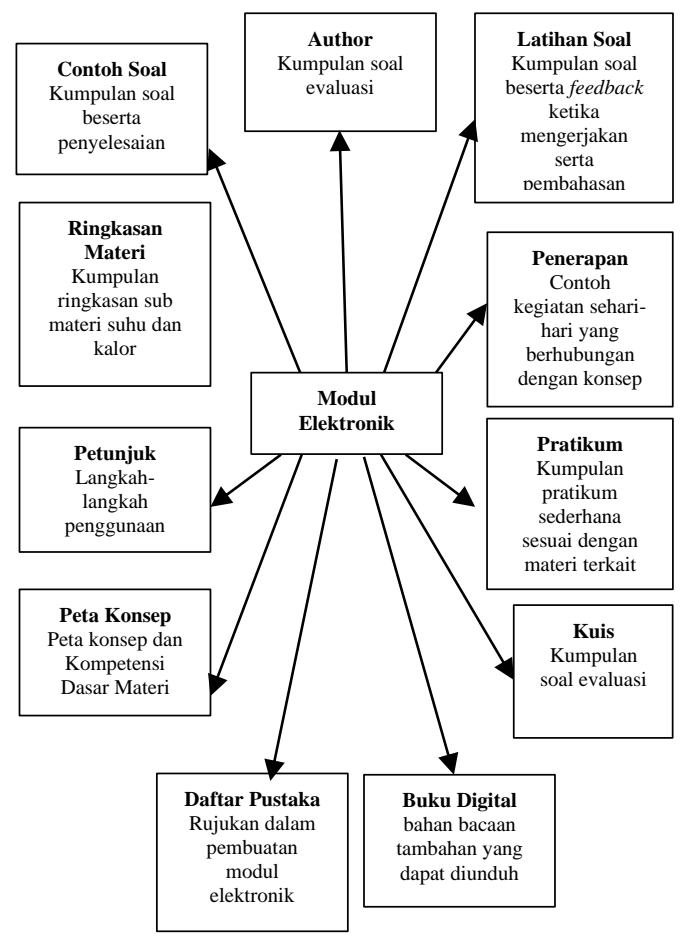

Gambar 1. Kerangka Modul Elektronik

Hasil validasi konten oleh validator, aspek pada buku digital mendapatkan nilai rendah 3.25/valid yang mendapatkan masukan dari validator terkait tampilan utama buku digital. Aspek latihan soal yang terdapat fitur feedback di dalamnya memperoleh nilai rata-rata sebesar 3,78 dengan masukan untuk menambahkan petunjuk dan mengubah kata peprindahan menjadi perpindahan. Aspek pratikum mendapatkan nilai rata-rata sebesar 3,62 dengan masukan untuk menambahkan informasi bahwa LKS pada modul elektronik tersebut tidak dapat diketik sehingga dibutuhkan penjelasan dalam pada aspek pratikum.

Tabel 4. Hasil Validasi Aspek Konten

\begin{tabular}{cc}
\hline Kategori & Nilai \\
\hline Materi & 3.6 \\
Contoh Soal & 3.7 \\
Latihan Soal & 3.8 \\
Penerapan & 4.0 \\
Pratikum & 3.6
\end{tabular}




\begin{tabular}{cc}
\hline Kategori & Nilai \\
\hline Buku Digital & 3.2 \\
Peta Konsep & 3.5 \\
Kuis & 3.7 \\
\hline
\end{tabular}

Aspek pada peta konsep memperoleh nilai rata-rata validasi sebesar 3,45 dengan masukan untuk mengganti kata kerja pada IpKD menjadi kata kerja yang dapat diukur. Kemudian aspek kuis memperoleh nilai ratarata 3,83 dengan masukan untuk memberi petunjuk ketika pengguna berada pada laman quizizz yang ingin kembali menuju aplikasi iemophy. Aspek materi memperoleh nilai rata-rata sebesar 3,63 dengan masukan untuk menambahkan pertanyaan dasar atau yang sering dijumpai dalam kehidupan sehari-hari terkait apersepsi sesuai dengan materi. Aspek Contoh Soal mendapatkan nilai rata-rata sebesar 3,71 serta aspek penerapan, memperoleh nilai rata-rata sebesar 4,00 dengan kategori tanpa revisi.

\section{Validasi Aspek Konstruk}

Dalam validasi aspek konstruk, validator melakukan penilaian terkait tampilan atau tata letak. Terdapat 4 aspek konstruk yang menjadi penialaian validator yaitu bahasa, gambar dan animasi, tampilan warna dan font, serta musik. Rekapitulasi hasil validasi konstruk yang diberikan oleh validator ditunjukkan pada Tabel 5.

Pada aspek Bahasa, diperoleh nilai rata-rata sebesar 3,53 dengan kategori valid tanpa revisi. Penilaian pada aspek ini, validator menilai terkait tata bahasa, kemudahan bahasa untuk dipahami atau komunikatif serta bahasa yang digunakan tidak menimbulkan miskonsepsi.

Pada aspek Gambar dan animasi diperoleh nilai rata-rata sebesar 3,67 dengan kategori valid tanpa revisi. Pada aspek ini validator menilai terkait kejelasan gambar dan animasi pada modul elektronik sehingga pengguna tidak sulit memahaminya. Namun, masih terdapat gambar/animasi yang kurang sesuai dengan kebutuhannya. Pada aspek ini validator mneyarankan untuk melakukan revisi terkait tampilan yang mengganggu.

Aspek warna dan font, mendapatkan nilai rata-rata sebesar 3,48 dengan kategori valid tanpa revisi. Pada aspek tersebut validator menilai mengenai ukuran dan jenis huruf yang digunakan serta kesesuaian tata letak hiasan/ilustrasi pada setiap pokok bahasan. Pada aspek ini, validator menyarankan revisi untuk mengganti font atau latar belakang yang memiliki intensitas cahaya yang sama (gelap-gelap, terangterang). Hal ini mengakibatkan keterbacaan huruf yang kurang jelas dalam menyampaikan informasi.

Hasil validasi aspek konstruk oleh validator, pada Aspek musik memperoleh nilai rata-rata paling rendah yaitu 3,00 dengan kategori valid dengan revisi. Masukan dari validator antara lain menghapus instrument/musik yang tedapat pada modul elektronik atau mengganti instrument yang sesuai dengan kriteria orang banyak. Berdasarkan keempat aspek tersebut, hasil analisis konstruk secara keseluruhan modul elektronik iemophy mendapatkan nilai rata-rata sebesar 3,44 yang berarti modul elektronik memiliki kriteria valid apabila dilihat dari segi konstruknya.

Tabel 5. Hasil Validasi Aspek Konstruk

\begin{tabular}{cc}
\hline Kategori & Nilai \\
\hline Bahasa & 3.5 \\
Gambar dan Animasi & 3.7 \\
Tampilan Warna dan Font & 3.5 \\
Musik & 3.1 \\
\hline
\end{tabular}

\section{Validasi Aspek Android}

Penilaian validasi aspek android terdiri dari 2 kategori, yaitu panduan modul elektronik dan operasional produk. Rekapitulasi hasil validasi android yang 
diberikan oleh validator ditunjukkan pada Tabel 6.

Pada aspek panduan modul elektronik, nilai rata-rata yang diperoleh sebesar 3,33 kategori valid tanpa revisi. Pada aspek ini validator melakukan penilaian terkait kejelasan petunjuk modul elektronik. Terdapat masukan dari validator untuk merevisi modul elektronik ini dalam segi panduan yang meliputi penambahan petunjuk secara eksplisit terkait tombol navigasi ketika mencoba fitur latihan soal.

Aspek yang kedua yaitu operasional produk, yang memperoleh nilai rata-rata sebesar 3,38 dengan kategori tanpa revisi. Penilaian yang dilakukan validator pada aspek ini terkait kemudahan instalasi dan pengoperasional produk, tata letak komponen dan navigasi, serta kemudahan tombol navigasi. Terdapat beberapa masukan yang diberikan oleh validator meliputi penambahan tombol menu utama disetiap layar dan memperbesar tombol navigasi.

Tabel 6. Hasil Validasi Aspek Android

\begin{tabular}{cc}
\hline Kategori & Nilai \\
\hline Operasional Produk & 3.4 \\
Panduan & 3.3 \\
\hline
\end{tabular}

\section{Tahap Implementation}

Modul elektronik yang dikembangkan telah diujicobakan secara terbatas kepada 85 siswa kelas XI MIPA di SMAN 1 Asembagus dan SMAN 2 Situbondo. Aspek yang dinilai pada ujicoba terbatas ini antara lain Tampilan, Bahasa, Materi, Latihan Soal, instalasi Android. Siswa merasa penggunaan modul elektronik pada proses pembelajaran dapat meningkatkan minat mereka, dimana warna tampilan dan kemudahan mengoperasikan aplikasi menunjang siswa merasa senang mempelajari materi Suhu dan Kalor. Namun beberapa siswa merasa font pada aplikasi kurang besar, ukuran aplikasi terlalu besar dan prosedur instalasi aplikasi perlu dipermudah.
Berdasarkan hasil analisis validasi oleh validator diketahui bahwa modul elektronik yang dikembangkan termasuk pada kriteria valid dengan revisi. Modul elektronik yang dikembangkan menyajikan ringkasan materi sesuai dengan Kompetensi dasar. Fitur pada Contoh Soal, Latihan Soal serta Kuis sesuai disajikam sesuai dengan IpKD. Terjadi beberapa perubahan pada font, gambar, serta musik. Selain itu, terdapat penambahan ikon menuju menu utama, penambahan petunjuk pengoperasian di beberapa fitur tertentu pada modul elektronik ini.

Kriteria modul elektronik yang dikembangkan, pertama bersifat user friendly yang artinya perintah dan informasi yang tertera pada modul elektronik tersebut membantu pengguna dalam mengoperasikan modul. Kedua adaptif, materi di dalamnya tetap dapat digunakan walaupun terjadi perubahan perkembangan jaman. Selain itu bahasa yang digunakan mudah dipahami dan komunikatif. Terdapat gambar serta animasi untuk membantu menjelaskan maksud materi tersebut. Terdapat latihan soal dan kuis untuk mengukur pemahaman konsep dan materi siswa pada materi suhu dan kalor. sistem feedback yang terdapat pada latihan soal membantu siswa. Memuat buku digital sebagai referensi tambahan pendukung materi.

\section{Tahap Evaluation}

Berdasarkan data hasil uji coba keterbacaan yang ditunjukkan pada Tabel 7 diperoleh nilai rata-rata presentase sebesar $79,31 \%$. Nilai tersebut termasuk kategori pertama dalam skala keterbacaan, menurut Arikunto (2006). Artinya, modul elektronik dengan feedback dapat terbaca oleh siswa.

Tabel 7. Hasil Uji Coba Keterbacaan

\begin{tabular}{cc}
\hline Kategori & Nilai \\
\hline Tampilan & 3.6 \\
Bahasa & 3.7
\end{tabular}




\begin{tabular}{cc}
\hline Kategori & Nilai \\
\hline Materi & 3.8 \\
Instalasi dan Android & 4.0 \\
Motivasi & 3.6 \\
Feedback & 3.2 \\
\hline
\end{tabular}

\section{PENUTUP}

Penelitian dan Pengembangan yang dilakukan menghasilkan produk akhir berupa modul elektronik dengan feedback berbasis android materi suhu dan kalor. Modul elektronik yang dikembangkan memiliki 11 menu utama, diantaranya ringkasan materi, peta konsep, contoh soal, latihan soal, penerapan, buku digital, kuis, pratikum, daftar putaka, author dan petunjuk e-modul. Produk yang telah dikembangkan, dilakukan uji validasi oleh validator (satu dosen fisika dan dua guru fisika) yang diperoleh nilai rata-rata sebesar 3,49. Selain itu, dilakukan uji keterbacaan modul dengan responden sebanyak 85 siswa yang diperoleh nilai ratarata sebesar 79,3\%. Berdasarkan data yang diperoleh, dapat dikatakan bahwa modul elektronik memiliki kriteria layak.

Dalam mengembangkan modul elektronik perlu diperhatikan beberapa hal, diantaranya: 1) mengetahui pengertian, kriteria dan penyusunan suatu modul, 2) memilih materi yang akan dipilih, serta mempersiapkan IPKD sebagai pedoman penyusunan materi dan soal-soal, 3) mengetahui cara membuat aplikasi menggunakan software yang dipilih, sebelum membuat aplikasi dalam skala besar, buatlah aplikasi dalam skala kecil hingga benar-benar bisa digunakan aplikasi tersebut. Pengembangan modul elektronik ini hanya terbatas sampai uji validitas dan uji keterbacaan. Pengembangan produk ini dapat dilakukan dengan uji efektifitas pada proses pembelajaran.

\section{REFERENSI}

Ali, M. (2009). Pengembangan media pembelajaran interaktif mata kuliah medan elektromagnetik. Jurnal Edukasi Elektro, 5(1).11-18.

Arianti, B. I., Sahidu, H., Harjono, A., \& Gunawan, G. (2017). Pengaruh model direct instruction berbantuan simulasi virtual terhadap penguasaan konsep siswa. Jurnal Pendidikan Fisika dan Teknologi, 2(4), 159-163.

Arikunto. (2006). Prosedur Penelitian Suatu Pendekatan Praktek. Jakarta: PT. Rineka Cipta.

Arista, F. S., \& Kuswanto, H. (2018). Virtual Physics Laboratory Application Based on the Android Smartphone to Improve Learning Independence and Conceptual

Understanding. International Journal of Instruction, 11(1), 1-16.

Conde, Miguel Ángel, and David Fonseca. (2018). Information Society Skills: Is Knowledge Accessible for All? Part I. Pp. 223-27 in Universal Access in the Information Society. Vol. 17.

Fathoni, M. I., \& Marpanaji, E. (2018). Pengembangan e-book interaktif mata pelajaran teknologi informasi dan komunikasi (TIK) untuk SMK kelas X. Jurnal Inovasi Teknologi Pendidikan, 5(1), 70-81.

Ghaliyah, S., Bakri, F., \& Siswoyo, S. (2015). Pengembangan modul elektronik berbasis model learning cycle $7 \mathrm{E}$ pada pokok bahasan fluida dinamik untuk siswa SMA kelas XI. In Prosiding Seminar Nasional Fisika (E-Journal) (Vol. 4, pp. SNF2015-II).

Herawati, N. T. (2017). The Implementation of Self-Regulated Learning Model Using ICT Media Toward the Students Achievement in Introduction to Accounting Course.Journal of Accounting and Business Education, 2(1), 144-157.

Herayanti, L., Gummah, S., Sukroyanti, B. A., Gunawan, G., \& Makhrus, M. 
(2018). Pengembangan Perangkat Pembelajaran Berbasis Masalah Meggunakan Media Moodle Untuk Meningkatkan Keterampilan Berpikir Kritis Mahasiswa Pada Materi Gelombang. Jurnal Pendidikan Fisika dan Teknologi, 4(2), 158-167.

Hörisch, J., Wulfsberg, I., \& Schaltegger, S. (2019). The Influence of Feedback and Awareness of Consequences on the Development of Corporate Sustainability Action Over Time. Business Strategy and the Environment. (August):1-13.

Mardiana, N., \& Kuswanto, H. (2017). Android-assisted Physics Mobile Learning to Improve Senior High School Students' Divergent Thinking Skills and Physics HOTS. In AIP Conference Proceedings (Vol. 1868, No. 1, p. 070005). AIP Publishing LLC. (August)

Mariki, B. E. (2013). Use of ICT in Distance Education at Hanyang Cyber University: Possible Best Practices for The Institute of Adult Education. Turkish Online Journal of Distance Education, 14(2), 185-195.

Mihaela, Paisi Lăzărescu, \& Stan Maria Magdalena. 2017. "Student Centered Learning Using ICT.” Pp. $1-4$ in Proceedings of the 9th International Conference on Electronics, Computers and Artificial Intelligence, ECAI 2017.

Rahayu, P., Prastowo, S. H. B., \& Harijanto, A. (2018). Indentifikasi Pemahaman Konsep Fisika Pokok Bahasan Suhu Dan Kalor Melalui Three Tier Test Pada Siswa Sma Kelas XI. FKIP ePROCEEDING, 3(1), 226-230.

Rahman, H. (2014). The role of ICT in open and distance education. Turkish Online Journal of Distance Education, 15(4), 162-169.

Sahidu, H., Gunawan, G., Indriaturrahmi, I., \& Astutik, F. (2017). Desain Sistem EAssessment pada Pembelajaran Fisika di LPTK. Jurnal Pendidikan Fisika dan Teknologi, 3(2), 265-270.

Sugiana, I. N., Harjono, A., Sahidu, H., \& Gunawan, G. (2017). Pengaruh Model Pembelajaran Generatif Berbantuan Media Laboratorium Virtual Terhadap Penguasaan Konsep Fisika Siswa pada Materi Momentum dan Impuls. Jurnal Pendidikan Fisika dan Teknologi, 2(2), 61-65.

Sugiono. (2015). Metode Penelitian Pendidikan. Bandung: Alfabeta.

Widyawati, A., \& Prodjosantoso, A. K. (2015). Pengembangan media komik IPA untuk meningkatkan motivasi belajar dan karakter peserta didik SMP. Jurnal Inovasi Pendidikan IPA, 1(1), 24-35.

Yoon, Hyeon-Ju. (2012). A Study on the Performance of a Gyromonotron. International Journal of Infrared and Millimeter Waves, 4(4):437-52.

Yot-Domínguez, Carmen, and Carlos Marcelo. (2017). University Students' Self-Regulated Learning Using Digital Technologies. International Journal of Educational Technology in Higher Education, 14(1).

Yulianci, S., Gunawan, G., \& Doyan, A. (2017). Model Inkuiri Terbimbing Berbantuan Multimedia Interaktif Untuk Meningkatkan Penguasaan Konsep Fisika Peserta Didik. Jurnal Pendidikan Fisika dan Teknologi, 3(2), 146-154. 